\title{
Caminhos do Teatro Infanto-Juvenil
}

Cibele Troyano *

O ano de 1948 pode ser considerado como um marco na história do teatro infanto-juvenil brasileiro. Até então o teatro para crianças, a despeito de contar com autores da envergadura de Olavo Bilac, por exemplo, obedecia a propósitos estritamente didáticos e moralistas.

A montagem de $O$ Casaco Encantado, de Lucia Benedetti, com produção de Paschoal Carlos Magno e um elenco que contava com atores profissionais de renome, como Henriette Morineau, inaugura, por assim dizer, a nova modalidade teatral. Seus princípios eram idênticos aos que nortearam os fundadores do moderno teatro brasileiro: ampliar as platéias, proporcionando-Ihes uma verdadeira experiência estética e assim socializar a cultura.

Sucederam-se, ao longo da década de 50, encenações de diversas peças infanto-juvenis que, além do sucesso junto ao público, passaram a merecer a atenção dos mais respeitados críticos de teatro da época, tais como Décio de Almeida Prado, Carlos Drummond de Andrade, Manuel Bandeira, Barbara Heliodora, Yan Michalski e Paulo Francis.

Se em seu percurso o teatro infantil, seja por razões políticas ou de mercado, distanciou-se da vocação estética que motivou a geração dos anos 50 , é necessário ressaltar que houve, por outro lado, um importante avanço em sua dramaturgia.

Dentre os responsáveis por este avanço está o autor e encenador paulista Vladimir Capella.

Capella inicia sua carreira em 1978. Desde então, tem sistematicamente encenado seus textos que, apesar do reconhecimento da crítica especializada, ainda não obtiveram a devida atenção por parte de estudiosos e pesquisadores.

Sua obra foi objeto de minha dissertação de mestrado: O enigma da

* Cibele Troyano, atriz e socióloga, mestre em teatro e educaçãopela na ECA-USP. 
A análise de sua obra traz à tona umas das mais polêmicas questões que o teatro infantil suscita: sua especificidade ou não enquanto modalidade artística.

A controvertida discussão divide as opiniões. De um lado estão os que, contrários a qualquer distinção entre teatro adulto e teatro infantil, argumentam que demarcar aprioristicamente fronteiras etárias para o teatro implica em acentuar a desigualdade entre o emissor da mensagem (sempre um adulto) e o receptor (a criança). Esta prática tem como conseqüência a produção de textos de qualidade artística duvidosa, seja por seu caráter didático e moralista, seja por sua deliberada simplificação estética.

Dentre os representantes desta corrente está Maria Lúcia de Souza Barros Pupo. Suas idéias estão expostas no livro No reino da desigualdade, publicado em 1991 pela editora Perspectiva.

De outro lado, encontram-se os que defendem a especificidade do teatro infantil. Segundo estes, o teatro para crianças teve início em 1948, e desenvolveu ao longo de sua história uma poética própria, que apresenta certa independência em relação ao teatro adulto.

Nas páginas de Maria Clara Machado, de Claudia de Arruda Campos, publicado pela EDUSP em 1998, pode-se encontrar uma detalhada defesa destas idéias.

A irresolvida discussão ganha novos contornos a partir do trabalho desenvolvido por Vladimir Capella. Um breve panorama de sua dramaturgia será aqui traçado, com o intuito de mostrar em que medida isto acontece.

O texto de estréia de Capella, escrito em parceria com José Geraldo Rocha, Panos e Lendas, é um espetáculo musical, cuja dramaturgia tem como princípios a dessacralização do texto, a quebra da quarta parede e do palco italiano, o predomínio do elemento lúdico e a explicitação das convenções teatrais, premissas que caracterizaram o teatro dos anos 60 e 70.

Com um cenário flexível e um figurino que se transforma às vistas da platéia, a peça conta a história do mundo, conforme a mitologia indígena. O texto trata do ciclo da vida, através de dois personagens centrais, o índio Caru e seu filho Rairu.

Com as inúmeras canções que compôs especialmente para o espetá- 
culo, Vladimir Capella recebeu, por Panos e Lendas, um Molière, o mais importante prêmio então conferido ao teatro. Premissas estéticas semelhantes foram aplicadas em Avoar, texto escrito em 1980 e encenado em 1985.

A peça trata das perdas decorrentes da vida nas grandes metrópoles. Avoar é um texto composto quase que exclusivamente por canções folclóricas, parlendas e brincadeiras. Sua originalidade consiste na escolha e no encadeamento das cantigas e dos brinquedos em torno de um conflito central: como trazer de volta à cidade cinzenta uma lua, uma palmeira e uma canção. Após uma longa viagem em busca destes elementos, o conflito é solucionado através da arte: ao entoarem a canção que dá nome à peça, os personagens trazem a lua de volta, que chega acompanhada por um céu estrelado.

Como a Lua, escrita e encenada em 1981, apresenta a primeira personagem capelliana: Payá, um índio que nasce predestinado a sofrer por amor. Desesperado por ter sido abandonado pela amada, ele morre de tristeza, despertando a compaixão do deus Rudá, que lhe permite dormir por cem anos. Passado este tempo, Payá ressurge em meio a um centro urbano, na figura de um palhaço.

Os recursos utilizados por Vladimir para falar à criança sobre a dor provocada por um amor não correspondido abrem novos caminhos para sua então nascente dramaturgia.

A solução encontrada foi a de mostrar o drama de Payá em um plano mítico, ocorrido em um tempo distante - o princípio do mundo - e entremeálo com cenas urbanas, protagonizadas por crianças contemporâneas. Estas, com suas dúvidas e inquietações em relação ao amor, ao nascimento e à morte, traçam um paralelo entre ambos os tempos da ficção, estabelecendo uma dialética entre os conflitos de Payá e os seus próprios.

A quebra das dimensões convencionais de tempo e de espaço é radicalizada em Antes de ir ao Baile, encenada em 1986. Desta vez, passado, presente e futuro são tratados aleatoriamente no transcurso da peça, até serem mostrados de forma simultânea na cena final, em que se dá o encontro de quatro velhos com sua infância e de quatro crianças com sua velhice.

A história de quatro velhos, que viajam em direção à morte num pequeno barco azul, é alternada com a de quatro crianças em busca de aventuras. Entre ambas as histórias, um professor de artes é constantemente mencionado pelas crianças, que se inquietam com as questões que ele suscita sobre a vida, a morte, o futuro. 
Por fim, ocorre o inusitado encontro entre os velhos e as crianças. Conversam, trocam afetos e objetos, compõem uma canção. As crianças então se despedem e assumem o lugar dos velhos no barco, rumando para o desconhecido.

Em Antes de ir ao Baile não há protagonistas. As personagens são mostradas menos por sua história do que por algumas lembranças e projeções que têm dela. Não há um conflito dramático explícito. Há uma única canção, apresentada em diversos momentos da peça com diferentes arranjos musicais, que funciona como um leitmotiv, prática inédita até então no teatro infantil.

Pode se dizer que Como a Lua e Antes de ir ao Baile modificaram a história do teatro infanto-juvenil, tanto por sua ousada construção dramatúrgica, como pela abordagem de temas nem sempre considerados afeitos às crianças, como o desejo, a paixão, a velhice e a morte.

Prosseguindo em sua pesquisa, Capella, ainda na década de 80 , redescobre os contos de fadas, sob a ótica de Bruno Bettelheim.

Em seu, hoje clássico, Psicanálise dos contos de fadas ${ }^{2}$, o psiquiatra austríaco Bruno Bettelheim analisa os mais populares contos de fadas, discutindo suas repercussões na psiquê da criança.

Bettelheim trouxe uma preciosa contribuição para toda uma geração que lutara por transformar os paradigmas da Educação, ao argumentar que os contos de fadas são fundamentais na formação psíquica de qualquer criança, que neles encontra os significados profundos de sua própria existência. A criança, através desses contos, segundo ele, é capaz de elaborar questões complexas como a morte, o envelhecimento, as dores, as paixões e os medos e assim enfrentar seus próprios conflitos.

Influenciado por estas idéias, Capella adapta a história de Cinderela. E desde logo, o faz de uma maneira singular: a matriz escolhida é a versão recolhida em Sergipe por Silvio Romero, Maria Borralheira.

Ainda que baseado na matriz bettelheimiana, Capella transcende as prerrogativas estritamente pedagógicas que o autor atribui aos contos de fadas, construindo personagens isentos de quaisquer maniqueísmos, com traços psicológicos e conflitos interiores bastante desenvolvidos, dotando o texto de múltiplas leituras.

Maria Borralheira aborda os mesmos temas que até então caracteriza- 
ram a dramaturgia de Vladimir Capella. Entretanto, o conto de fadas tornou possível mostrar questões como a sexualidade e a morte de forma mais explícita.

Assim por exemplo, a peça tem início com um solene funeral, mostrando a morte da mãe de Borralheira. Em determinado momento, aparece em cena o corpo morto da vaquinha Lua, amiga da protagonista, e assassinada pela madrasta. O príncipe Bernardo apaixona-se por Maria Borralheira, ao vê-la banhando-se nua em uma cachoeira.

Talvez por se tratar de um conto de fadas, a peça é construída com maior linearidade que as anteriores (apesar de conter uma cena de flash back) e requer cenários e figurinos mais suntuosos. O espetáculo se aproxima das grandes encenações que tomaram os palcos durante a segunda metade dos anos 80 .

As montagens subseqüentes de Vladimir Capella mantêm o caráter grandioso inaugurado com Maria Borralheira, com exceção de O Dia de Alan, a peça que a sucedeu.

Neste texto, escrito em 1988, Vladimir fez a experiência de aplicar a estrutura do conto de fadas numa história realista e contemporânea. Alan é um menino pobre, que convive com o preconceito de seus colegas de escola. A dor pela morte da professora de artes, com a qual mantinha uma relação maravilhosa, conduz o protagonista a enfrentar a estrutura escolar, que tudo faz para o excluir. Um boneco que tinha sido criado por ele na aula de artes e que fora destruído pelos colegas, ressurge como um super herói e o auxilia a dominar a classe e a expor seu desejo de ser respeitado. Durante seu discurso, Alan despe-se diante de todos que, sensibilizados, colocam sobre ele um manto e uma coroa e o proclamam rei.

A opção de Capella de colocar Alan completamente despido, na cena final da peça, fez com que o espetáculo não fosse bem aceito pelas escolas, limitando assim a temporada do espetáculo que, entretanto, foi muito bem aceito pela crítica.

Um novo caminho da dramaturgia de Vladimir Capella é aberto com uma pesquisa em torno da mitologia grega. O resultado foi o texto Píramo e Tisbe, escrito e encenado em 1990. A história do amor impossível dos jovens Píramo e Tisbe é construída pouco a pouco ao longo do texto, que se inicia com o mito grego da criação. A tragédia do casal de amantes é precedida por uma série de histórias de amor igualmente trágicas, como a de Eco e Narciso e a de Orfeu e Eurídice, que preparam o público para acompanhar o triste 
destino dos jovens protagonistas.

Provavelmente pela riqueza do material pesquisado por Capella, o texto resultou mais longo do que os que o antecederam. Os discursos de todas as personagens colocados na segunda pessoa e seu vocabulário mais rebuscado foram recursos indispensáveis para que o autor obtivesse da platéia a emoção pretendida. Por estas razões, Píramo e Tisbe resultou um espetáculo menos acessível às crianças pequenas. Guardadas as ressalvas ao termo, que reascende a velha polêmica, a peça poderia ser classificada como "teatro jovem", modalidade inaugurada há cerca de 10 anos, com premiações e verbas próprias.

Aliás, já em 1984, Vladimir havia encenado Filme Triste, seu único texto apresentado como "teatro adulto", sobre a vida da juventude dos anos 60 . Por tratar de temas políticos e históricos menos próximos do mundo infantil, a peça pode ter sido uma das precursoras deste mesmo "teatro jovem".

Em 1992, ocorre a primeira adaptação literária. Por encomenda de um produtor, Capella escreve O Saci, a partir do livro de Monteiro Lobato, autor que curiosamente não conhecera na infância. $O$ encontro, segundo um depoimento de Vladimir, fez com que ele tomasse mais consciência de seu próprio trabalho e compreendesse melhor toda a literatura infanto-juvenil contemporânea: "Fiquei deslumbrado como quando se acha a fonte, o nascedouro de uma grande cachoeira”.

$\mathrm{Na}$ adaptação do conto, pode-se identificar os temas recorrentes na dramaturgia capelliana: os medos, a morte, a descoberta da sexualidade: Pedrinho quer descobrir os segredos da mata. Escraviza o Saci e empreende com ele uma aventura para salvar Narizinho, raptada pela Cuca. Nesta empreitada, conhece alguns mistérios da vida, como desejo e a paixão, que experimenta ao admirar a lara banhando-se desnuda.

No final da aventura, Pedrinho sai vitorioso, libertando a prima. É aclamado como um herói. Ao ser interrogado sobre a lara, ele não revela que a conhecera. O menino transformara-se. Descobrira os segredos do amor. As lendas brasileiras são retomadas, agora focalizando as principais personagens deste universo: A lara, o boitatá, o curupira, etc. A música, como sempre, exerce um papel fundamental, destacando-se uma gravação exclusiva da Bachiana número 5, de Vila Lobos, por Vânia Bastos, utilizada como "o canto da lara" para seduzir Pedrinho.

A aproximação entre a dramaturgia de Capella e a literatura infanto-juvenil gerou quatro textos, escritos entre 1996 e 2001, nos quais são abordadas 
não só as obras, mas as próprias biografias de seus autores. A novidade trazida por Capella nestes textos é a de transformar em personagens os autores focalizados, inseri-los nos seus próprios universos ficcionais e, através deste recurso, discutir o próprio fazer artístico.

O papel da arte e da criação artística, sempre presentes na dramaturgia de Vladimir Capella, ganha destaque neste grupo de textos. ${ }^{3}$

O Homem das Galochas, sobre a vida e obra de Hans Christian Andersen, é o primeiro deles. O texto foi escrito em 1996 e revisto em $1997^{4}$

Hans Christian Andersen aparece como o principal personagem de $O$ Homem das Galochas. O texto promove um estranho encontro entre o poeta em seus derradeiros momentos de vida e o pequeno Hans. As galochas mágicas que possibilitaram tal encontro permitem também que Andersen possa manifestar seu último desejo. Ele as calça e incumbe o menino de continuar contando suas histórias, (que foram apresentadas ao longo da peça). O menino pergunta o nome do poeta e se surpreende ao descobrir que ambos eram a mesma pessoa, Hans Christian Andersen.

Capella mostra o ciclo de vida do personagem, estabelecendo um jogo entre ficção e realidade, no qual os contos selecionados são apresentados como fatos de vida do escritor e os fatos de sua vida como histórias de ficção. Assim por exemplo, há uma passagem do texto na qual a mãe do menino insiste em fazê-lo freqüentar a escola e deixar de sonhar em ser um artista importante. Achando graça de seus desejos ela lhe diz que ele se "parece com um patinho feio que sonha sonhos de cisne", dando a impressão de que a frase teria inspirado o famoso conto que ele viria a escrever no futuro.

Os demais textos deste grupo são O Clone do Visconde, O Gato Malhado e a Andorinha Sinhá e O Colecionador de Crepúsculos, que serão comentados mais abaixo.

Em 1999, após O Homem das Galochas, Vladimir retoma o conto de fadas, com uma história criada por ele, sempre em consonância com as premissas de Bettelheim.

Clarão nas Estrelas conta a história de um príncipe que beira à loucura, devido a um feitiço imposto por sua autoritária mãe. É salvo por uma criada do palácio, Maria, que depois de enfrentar, com a ajuda de seu pêndulo mágico, as perseguições da rainha, dá um tiro de espingarda no príncipe, libertando o pássaro que o habitava. Ambos se casam no final. 
O texto tem uma construção bastante complexa. Com vários focos de narratividade e uma estrutura circular, a trama tem início com Maria atirando no príncipe, para a seguir voltar no tempo e contar a história de ambos. Os relatos de Maria ao príncipe sobre sua infância e a perda de seus pais são construídos de modo a tornar simultâneas ação e narração. A peça, além dos temas sempre tratados pelo teatro de Vladimir Capella, introduz novas questões, como por exemplo, a depressão e a loucura. Além disso, ressalta a importância do auto-conhecimento como meio indispensável à realização da pessoa humana: "É preciso conhecer tua história... para saberes quem és", diz Maria ao príncipe.

No mesmo ano, o inquieto Capella realiza uma nova experiência dramatúrgica: escreve Imagens, um roteiro para um espetáculo teatral sem palavras, com música ilusionismo e circo.

Escrito para ser apresentado no parque de diversões Hopi Hari, Imagens explora os mais impressionantes recursos visuais, sem deixar de abordar os instigantes assuntos que integram o universo temático capelliano. Vida e morte, desejo e sexualidade são abordados neste texto com menos de 10 páginas. A peça versa sobre de uma noiva raptada por um mago do mal, no dia de seu casamento. O noivo sai à sua procura, enfrenta o terrível mago e, ao arrancar sua máscara, descobre que ele e o mago eram a mesma pessoa.

O roteiro de Imagens, que pode ser considerado como uma grande rubrica, é exemplar para a retomada de uma antiga discussão suscitada pela dramaturgia contemporânea: a oposição texto e cena. Nos textos de Capella, as rubricas foram ganhando maior espaço ao longo do tempo, tornando difícil a separação entre o autor e o encenador. Algumas delas chegam a assumir feições literárias. Em Clarão nas estrelas, por exemplo, pode-se ler: "o importante é que o anjo esteja envolto numa indescritível luz". Vladimir afirma que seu desejo, ao escrever um texto de teatro, é que o leitor tenha uma perfeita visão daquilo que acontece em cena. Ressalva, contudo, que suas rubricas não pretendem impor a futuros encenadores a sua própria concepção de montagem, mas apenas torná-la a mais clara possível.

Miranda, escrita em 2000 e encenada em 2003 traz a história de uma menina que se veste de homem para enfrentar o mundo. Com ressonâncias de Diadorim, Maria Gomes, da literatura de Cordel, Joana D'Arc, Shakespeare e os contos medievais, Miranda parece completar o ciclo das personagens femininas criadas por Capella, a partir de Maria Borralheira. Para ser feliz, Miranda deve encontrar a própria identidade (como Borralheira), salvar o rei da loucura (como Maria, de Clarão nas Estrelas) e ainda libertar a cida- 
de da opressão política imposta pela rainha. A cura do rei e a conseqüente salvação da cidade só se tornam possíveis depois que Miranda lhe revela sua condição de mulher, desnudando-se perante ele.

Poder político, homossexualismo e incesto são os novos temas abordados por Vladimir Capella nesta peça que, em virtude da cena de nudez, foi impedida de estrear no teatro previsto, por determinação do diretor da escola que o administra. A proibição interrompeu bruscamente o compromisso firmado, de oferecer o espaço para uma temporada estável do espetáculo. Sem contar com qualquer patrocínio, Miranda esteve em cartaz por curtíssimo período em uma unidade do Sesc/SP.

Em 2001, Vladimir escreve seus mais recentes textos, focalizando autores literários e suas obras.

O Clone do Visconde retoma a obra de Monteiro Lobato, realizando uma verdadeira alegoria da criação literária. Lobato aparece como personagem e enfrenta um fato singular: Emília alterara uma de suas histórias, realizando um rico funeral para o Visconde de Sabugosa, que havia sido morto por uma jaca que lhe caíra na cabeça.

Admirado, ele chega a afirmar: "... mas eu não escrevi isso!" Intrigado com o atrevimento, ele descobre que o funeral era apenas um pensamento de Emília que, inconformada com a morte do amigo, desejara prestar-Ihe uma última homenagem.

Lobato, sensibilizado com as nobres intenções da boneca, admite que aquela história mereceria um final mais feliz. Procura-a e oferece sua ajuda para ressuscitar Sabugosa. Torna-se então coadjuvante de sua própria personagem e, sob as imperiosas ordens de Emília, traz o Visconde de volta. Um jogo semelhante é proposto por Capella em O Colecionador de Crepúsculos, sobre a vida e obra de Luis Câmara Cascudo. Desta vez o próprio Cascudo é salvo da morte pelas mãos de uma das personagens que imortalizou.

O compadre da Morte, o conto central do espetáculo, mostra a história de um caipira que dá seu filho para ser batizado pela Morte. Esta, em troca, o torna um médico de prestígio. Graças a este contrato, ele pode "prever" a cura ou não de um doente, conforme a posição ocupada pela comadre diante do leito. Ao longo da peça, Câmara Cascudo, mostrado por um boneco, aparece fazendo anotações, fumando seu charuto e apreciando o entardecer. Até que, em determinado momento o caipira, tomando conhecimento do delicado estado de saúde de Cascudo, vai visitá-lo. A Morte está posicionada 
de forma a indicar que não havia salvação possível. O caipira então a engana, mudando rapidamente a cama de lugar e salva vida do folclorista. Afirma ainda que Cascudo só morrerá no dia em que ele (o caipira) morrer. Depois de enganar a morte mais algumas vezes, o caipira é finalmente vencido por ela. Sua morte coincide com a de Cascudo.

A peça, composta dos vários "causos" e relatos recolhidos por Câmara Cascudo, parece fechar um ciclo da dramaturgia de Vladimir Capella produzida até o momento. O dramaturgo traça um painel, a partir dos contos recolhidos pelo folclorista, que sintetiza muitas das aventuras que ele próprio empreendeu em seu percurso. As ressonâncias de Panos e Lendas e Avoar, através das lendas e das canções brasileiras estão ao lado da abordagem dos mitos fundadores de nossa cultura, como a lara, já presente em O Saci. A adaptação do conto A menina enterrada viva, um dos episódios que compõem a trama, retoma, ainda que com personagens menos verticalizados, o mesmo universo simbólico dos demais contos de fadas trabalhados por Capella.

O Colecionador de Crepúsculos, texto cuja riqueza merece um estudo à parte, espera há três anos que surja um patrocínio para ser levado ao palco.

Também está inédito O Clone do Visconde, em virtude de problemas de direitos autorais junto à família de Lobato.

O Gato Malhado e a Andorinha Sinhá, a mais recente encenação de Vladimir é também uma adaptação literária em que o autor da obra aparece como personagem. Neste caso, Jorge Amado é colocado em cena dizendo ao filho que escrevera uma história, mas que iria contá-la com sua própria voz, pois o menino com apenas um ano de idade, ainda não podia compreender as letras. É interessante notar que, por meio desta fala, Capella faz com que o próprio Jorge Amado justifique a transposição de texto literário para o palco.

A obra de Vladimir Capella conta ainda com um pequeno romance infanto-juvenil : Fim que vira começo que vira, publicado em 1988 pela editora Acadêmica e textos para teatro de bonecos: Do outro lado e Sonhos, não abordados neste artigo.

Como músico compôs diversas canções, algumas gravadas por cantores profissionais, sem contar as que criou para seus espetáculos.

O teatro de Vladimir Capella é exemplar para a compreensão dos múlti- 
plos caminhos percorridos pelo teatro infantil brasileiro. Sua obra vem mostrar que quaisquer prescrições extra-artísticas, quando se trata de incluir crianças na platéia, tornam-se meios de discriminar e diminuir o próprio teatro.

Capella, ao abordar as grandes questões humanas em textos construídos com o máximo apuro estético faz de seu teatro uma arte para todas as idades.

Resta apontar quais as características de sua poética que permitem a aproximação do público infantil.

Em primeiro lugar, a recepção da criança é possibilitada pela poesia contida nos textos, que os torna sintéticos o bastante para permitir que sejam apreciados sem dispersão.

O emprego poético e sugestivo da palavra e os cuidados com os aspectos visuais (sempre recomendados nas rubricas), são qualidades que permitem que a recepção do espetáculo ocorra, sobretudo, através da sensibilidade.

A música, traduzida em belas canções cantadas ao vivo ou em sofisticados arranjos instrumentais, apresenta-se como uma linguagem co-participante do teatro capelliano e também se configura como um importante veículo de aproximação do seu teatro com o público infantil.

A criação de personagens infantis como seres pensantes, críticos e agentes de seu próprio destino, são fatores que também permitem a fruição e o deleite da criança.

Ao adulto, além do prazer sensível que estas opções estéticas igualmente lhe proporcionam, o teatro de Vladimir Capella permite muitas outras instâncias de produção de sentido.

A história do teatro infantil brasileiro dos últimos 25 anos é assim escrita por Vladimir Capella como uma história que busca, antes de tudo, romper limites e permitir que o prazer proporcionado pela arte possa ser compartiIhado por desiguais. Esta é sua grande contribuição.

\section{Notas}

${ }^{1}$ Disponível na Biblioteca da ECA/USP 
${ }^{2}$ Bettelheim, Bruno. Psicanálise dos contos de fadas. RJ: Paz e Terra, 1980

${ }^{3}$ Em toda a dramaturgia de Vladimir Capella, a arte desempenha um papel essencial na solução dos conflitos vividos pelas personagens. Por exemplo, em Avoar, é a canção que traz a lua de volta à cidade. Payá, de Como a lua, supera sua desilusão amorosa transformando-se em palhaço. Rosa, a protagonista de Filme Triste, vence a solidão tornando-se escritora. Alan impõe-se se diante dos colegas graças à ajuda do boneco que criara na aula de artes.

${ }^{4}$ Costuma ser uma prática de Capella retomar seus textos e reescrevê-los, ora atualizando-os no tempo, ora acrescentando rubricas com as descobertas decorrentes das encenações que realiza.

\section{Bibliografia}

BETTELHEIM, Bruno. Psicanálise dos Contos de Fadas. RJ: Paz e Terra, 1978.

CAMPOS, Claudia de Arruda. Maria Clara Machado. SP: Edusp, 1998.

LOMARDO, Fernando. O que é o Teatro Infantil? SP: Brasiliense, 1994. PAVIS, Patrice. Dicionário de Teatro. SP: Perspectiva, 1999.

PUPO, Maria Lucia de Souza de Barros. No Reino da Desigualdade. SP: Perspectiva, 1991.

PUPO, Maria Lucia de Souza de Barros. Palavras em jogo. Textos literários e Teatro-Educação. Tese de Livre-Docência apresentada à Escola de Comunicações e Artes da Universidade de São Paulo, 1997.

SANDRONI, Laura. De Lobato a Bojunga, as reinações renovadas. RJ: Agir, 1987.

SPOLIN, Viola. Improvisação para Teatro. SP: Perspectiva, 1992. TROYANO, Cibele. O enigma da morte no teatro de Vladimir Capella. Dissertação de mestrado apresentada à Escola de Comunicações e Artes da Universidade de São Paulo em 2003, sob a orientação da professora doutora Maria Lúcia de Souza Barros Puppo. 